\title{
Microbial Status of Animal Anatomical Cadavers Fixed Using Low Formaldehyde Concentrations
}

\author{
Al Aiyan A. ${ }^{1}$, Barigye R. ${ }^{1}$, Mohamed M.E.H. ${ }^{1}$, Menon P. ${ }^{1}$, \\ Hammoud M. ${ }^{1}$, Richardson K. ${ }^{2}$ \\ ${ }^{1}$ Department of Veterinary Medicine, College of Food and Agriculture, United Arab Emir- \\ ates University, Al Ain, UAE \\ ${ }^{2}$ College of Veterinary Medicine, School of Veterinary and Life Sciences, Murdoch Uni- \\ versity, Perth, Australia
}

With 1 table \& 2 plates

Received August, accepted for publication in September 2018

\section{Abstract}

Microbial growth on the skin and organ surfaces is a common problem associated with formaldehyde fixation of animal cadavers and is especially so following watering of cadavers prior to dissection. Cadavers of three sheep, one goat and three horses were fixed with a solution of $2 \%$ formaldehyde, $30 \%$ ethanol, and $20 \%$ polyethylene glycol 400 . At time intervals tissue samples of; skeletal muscle, lung and intestine were analyzed for cultivable aerobic bacteria, anaerobic bacteria and fungi. The aim of this study was to evaluate the effectiveness of a novel cadaver fixative solution having a $2 \%$ formaldehyde concentration. Visual examination of each fixed cadaver's skeletal muscles and visceral organs showed that these had retained a relatively natural appearance. No yeast or mould was cultured. Anaerobic bacteria namely Clostridium sporogenes and C. tyrobutyricum were isolated from the muscles of wo sheep. The aerobic bacterium Bacillus licheniformis was cultivated from the colon and duodenum of all three horses 40 days post fixation.

Keywords: Anatomy, dissection, embalming, formaldehyde, polyethylene glycol

\section{Introduction}

Animal cadavers remain a coreteaching tool for anatomists and veterinary medical educators teaching gross anatomy. Worldwide there have been a large number of individual embalming fluid formulations containing a great variety of; fixatives, disinfectants, surfactants, buffers, dyes, glycerol and salts used in the preparation of cadavers for dissection. Evaluations of these formulations have mostly focused on the 
aesthetics, both visual and tactile, of the fixed specimens. Few studies report on the disinfectant efficacy of the embalming fluids.

Historically most successful cadaver fixatives have been based on formaldhyde, a commonly used industrial fungicide and germicide. Even today, its antioxidant activity and ability to prevent microbial growth makes it popular for the preparation and preservation of human (Balta et al., 2015, Brenner, 2014) and animal cadavers (Janczyk et al., 2011b, Silva et al., 2007).

However, there are potential health risks associated with either exposure to high concentrations of formaldehyde or of long-term exposure to low concentrations of formaldehyde (IARC, 2006). This risk is low for students studying anatomy because their usual exposure is $2-5$ hours per week for 1 - 4 semesters of about 12 weeks each semester. However, for preparatory staff and academics handling specimens for longer periods, often over tens of years the risks are greater (IARC, 2006, Wantke et al., 2000). It is well known that formaldehyde affects not only the external contact surface of the body notably the skin and eyes but also causes irritation to the mucous membranes in the nose and throat (Chia et al., 1992, Dixit et al., 2005, Kim et al., 2002, Tanaka et al., 2003). In some individuals, even a brief exposure to concentrations of formaldehyde as low as 0.1 to $2 \mathrm{ppm}$ may cause coughing, nausea, as well as burning sensations in the eyes, nose and throat. Formaldehyde is known to have irritant effects on the respiratory tract and may induce adverse alterations in pulmonary function parameters and cellular morphology (IARC, 2006, Kriebel et al., 1993, Wantke et al., 2000). Chronic exposure has been linked to different types of cancer particularly those that involve the upper airway (Kerns et al., 1983). The U.S. Environmental Protection Agency (EPA) classified formaldehyde as a probable human carcinogen under conditions of unusually high or prolonged exposure (Agency, 1989).

Over many decades the maximum allowable concentration (MAK value) of formaldehyde fumes within the workplace has decreased from 0.5 ppm in 1989 to that recommended by the Senate Committee of the Deutsche Forschungsgemeinschaft as $0.3 \mathrm{ppm}(\mathrm{NIH}, 2009)$. The corresponding MAK value in the United States of America is $0.75 \mathrm{ppm}$ and in Japan it is $0.1 \mathrm{mg} / \mathrm{m}^{3}$ (Abdul-Wahab et al., 2015, Barsan, 2007). Consequently, over that timeline reducing the formaldehyde concentration in embalming fluid has become a major focus for anatomists to ensure a safe workplace for students and staff that regularly handle or dissect preserved cadavers.

Numerous embalming formulations have been developed with the aim of reducing the harmful effect of exposure to formaldehyde, but each has its own shortcomings such as; limited 
preservation life, undesirable microbial growth, tissue yellowing, damage to the anatomical texture of the tissue and in some instances high cost (Al-Hayani et al., 2011, Hammer et al., 2012, Macdonald and Mac Gregor, 1997). All of these limitations lessen their suitability for the longterm preservation and use of cadavers in anatomical dissections.

The use of non-formaldehyde based embalming solutions such as $\mathrm{N}$-vinyl-2-pyrrolidone (Haizuka et al., 2018), nitrite pickling salt (Janczyk et al.,2011a),polyhexamethylene guanidine hydrochloride (Anichkov et al., 2011) and dry shellac (Al-Hayani et al., 2011) have been and are being examined extensively. Fixatives like $\mathrm{N}$-vinyl-2-pyrro-lidone, polyhexamethylene guanidine hydrochloride were successful in preserving soft, elastic internal organs and a carcass with moderate joint motility. The other formaldehyde alternatives like nitrite pickling salt and shellac failed due to their causing the cadavers to be an unnatural colour and being corrosive (Al-Hayani et al., 2011, Anichkov et al., 2011, Haizuka et al., 2018, Janczyk et al., 2011a). Additional procedures such as rinsing cadavers in water before handling and engineering laboratory airflow to quickly remove cadaver fumes away from the breathing zone in dissection halls are used to reduce exposure to formaldehyde (Coleman and Kogan,
1998, Coskey and Gest, 2015, Janczyk et al., 2011a, Turan et al., 2017). Janczyk et al. (2011b) recommended that gas masks should be worn by those handling large animal cadavers held in formalin baths. Whilst anatomists have attempted to reduce formaldehyde exposure by watering formaldehyde-fixed cadavers prior to dissection, this practice is associated with microbial growth on the skin and organ surfaces (Janczyk et al., 2011b). To the best of our knowledge recent studies of new embalming solutions have not assessed the nature and effects of microbial growth isolated from formaldehyde preserved animal cadavers (Balta et al., 2015, Janczyk et al., 2011b, Turan et al., 2017). The aim of this study was to evaluate the effectiveness of a novel cadaver fixative with formaldehyde concentrations reduced to 2 percent. Our evaluation conducted on sheep, goat and horse cadavers included; assessing microbial and fungal growth inhibition, plus the pre- and post-embalming macroscopic assessment of muscles and internal organs. These evaluations were compared with species matched dissections of unfixed fresh specimens. However, the fresh cadaver dissections were undertaken over two days only.

The concentration of formaldehyde fumes in the air at working heights 
was assessed in the veterinary anatomy dissection hall of the Free University of Berlin.

\section{Material and Methods}

\section{Animal cadaveric specimens}

A total of seventeen adult animals i.e. six horses (200 to $300 \mathrm{~kg}$ ), eight sheep (40 to $50 \mathrm{~kg}$ ), and three goats $(35 \mathrm{~kg})$ were euthanased by a veterinarian in accordance with all relevant local animal welfare laws, guidelines, and policies (Landesamt für Gesundheit und Sozia-les Berlin). After the animals were anaesthetised, the left common carotid artery was catheterised for exsanguination. Three horses, three sheep, and a goat were subsequently fixed. The other three horses, five sheep and two goats were retained as fresh non-fixed cadavers.

\section{Formaldehyde based and other fixatives/preservatives}

To preserve the animal cadavers, a fixative solution consisting of $2 \%$ formaldehyde, $30 \%$ ethanol and $20 \%$ polyethylene glycol 400 , topped up with tap water to $100 \%$ was infused via the carotid artery using a peristaltic pump (MA-1450 Perfu-Tek, Medis $\mathrm{GmbH}$, Germany).

Approximately $9 \mathrm{~L} /$ sheep or goat and $60 \mathrm{~L} /$ horse of fixative were used. The cadavers of small ruminants were sealed in plastic bags and stored in a supine position at $5^{\circ} \mathrm{Cel}-$ sius until the bags were opened on the day of dissection. Horses were fixed in a standing position and stored at $5^{\circ}$ Celsius. Plastic bags were wrapped around the horse cadavers in the cold room to reduce any evaporation of the preservative fluid. Dissection of the horse cadavers was carried out twice weekly by students and veterinary educators over a period of five months. A solution of $30 \%$ ethanol and $20 \%$ polyethylene glycol made up to $100 \%$ with tap water was applied to all surfaces exposed by dissection on the cadavers after each dissection to prevent the cadavers from drying out when they were stored in the cold room.

As the dissections progressed, embalming parameters such as palpable consistency, muscle and joint flexibility, color, tissue hydration, and odour were assessed weekly after each dissection through a subjective assessment and palpation by preparatory and academic staff.

Major structures evaluated included; skeletal muscle in the field of dissection, then heart, lung, liver, spleen, kidney, stomach, small and large intestine, peripheral nerves and blood vessels as the dissections proceeded.

During the dissections of the fresh non-fixed cadavers (three horses, five sheep and two goats), the same 
parameters that were applied to evaluate the dissections of the fixed cadavers were used.

\section{Aerobic and anaerobic culture of cadaveric specimens}

Microbial investigations were conducted on tissue biopsies $(2 \times 2 \mathrm{~cm})$ of the superficial cervical trapezius muscle, deep within the longissimus thoraces muscle, superficial and deep biopsies of the cranial and middle parts of the left caudal lobe of the lung as well as tissue samples of the duodenum and descending colon. In all species, biopsies were taken 10 and 40 days after dissection commenced. In the horses, these were at 10 and 40 days post fixation whilst in the small ruminants biopsies were taken at 75 and 105 days post fixation. The samples were stored in clear, lidded, plastic tubes and the microbiological examination was performed according to standard procedures (Murray et al., 2007).

\section{Determination ambient formalde- hyde fumes concentrations}

Formaldehyde fumes in the air of the anatomy dissection laboratory were measured at one and three months after embalming. Here Formaldehyde-0.1 Detector Tubes (MSA Auer $\mathrm{GmbH}$, Berlin, Germany) were placed in the breathing zone $(0.5 \mathrm{me}$ ter above and at the side of animalcadavers). Air samples were col- lected by attaching the Formaldehyde-0.1 Detector Tube to KwikDraw Deluxe Detector Tube Pump (MSA Auer GmbH, Berlin, Germany). After sampling, the formaldehyde concentration was read directly from the scale printed on the tube.

\section{Results}

\section{Dissection parameters}

The weekly observations of the student's dissections show that the visual appearance of the cadavers remained close to their natural appearance. The muscles and fasciae retained most of their natural color and texture in the horses (Fig 1 A) but the skeletal muscles of the small ruminant cadavers appeared lighter than their natural colour. However, the muscles of all the cadavers developed a darker colour towards the end of the study period. This manifestation was more marked in horses than in the small ruminants. On palpation, the skeletal muscles of all cadavers were flexible and easy to dissect. However, the range of movement of the joints were limited and rigid when compared with fresh cadavers. All gross anatomical structures including arteries, veins and nerves were distinguishable and easy to dissect in all animals.

In all cadavers, the thoraco-abdominal organs such as the heart, lung, liver, spleen and kidneys were more rigid and had a darker hue than those in a non-fixed state (Fig 1B, C, 
D). The stomach, small and large intestines had an anatomic appearance close to that of non-fixed cadavers. Blood vessels and nerves were readily palpated and could be dissected easily. The adipose tissue had lost its normal colour as seen in freshly killed animals and had turned a light shade of gray.

\section{Microbial analysis}

In the current study, fungi were not cultured from any of the samples taken from the fixed cadavers. However, anaerobic bacteria, Clostridium sporogenes, and C. tyrobutyricum were isolated from the cervical trapezius muscle of two sheep. Paenisporosarcina sp. was cultured from the thoracic longissimus muscle of one horse. Similarly, Paenibacillus $\mathrm{sp}$. was cultured from the colon of one horse, and Bacillus sp. was cultured from the duodenum of the goat. Colonies of the Bacillus licheniformis were cultured from the duodenum and colon of all horses.

\section{Concentration of ambient formal- dehyde fumes}

The concentration of formaldehyde fumes measured in the breathing zone ranged from $0.05-0.15 \mathrm{mg} / \mathrm{m}^{3}$

\section{Discussion}

Ideally embalming fluids should maintain the natural colour and texture of the tissues and organs
(Coleman and Kogan, 1998) and should also prevent microbial growth over the time period of the anatomical dissection (Brenner, 2014). Historically, high concentrations of up to $10 \%$ of formaldehyde have been used in embalming fluids to prevent microbial growth however this has many adverse side-effects including rigidity and colour changes to the cadaver's tissues and organs (Brenner, 2014, Hammer et al., 2012, Silva et al., 2007).

In the current study, an embalming fluid consisting of; formaldehyde $(2 \%)$, ethanol $(30 \%)$, and polyethylene glycol $400(20 \%)$ made up by tap water to $100 \%$, was perfused via the left carotid artery into three sheep, one goat and three horses. In the fixed horses, muscle colour was similar to that of non-fixed horses but in the small ruminants, the muscles were slightly paler in colour than found in non-fixed ruminants. On palpation, the somatic muscles and joints of the fixed cadavers were a little more rigid than found in non-fixed cadavers. Similarly, the organs of all animals were more rigid and darker in colour than found in non-fixed cadavers.

According to Pretorius (1995) tissues preserved using higher concentration of formaldehyde $(12 \%)$ resulted in marked rigidity, which was ideal for 
tissue slicing but is not ideal for anatomy students who prefer tissue pliability and texture similar to that of the in-vivo state. Our study using a fixative solution at far lower concentration of formaldehyde $(2 \%)$ resulted in modest tissue flexibility. These results are consistent with the results of (Silva et al., 2007) where they used low formaldehyde concentrations $(0.3 \%)$ and reported that their dog cadavers were suitable for surgical training of veterinary medicine students.

This study used PEG, a polymer of ethylene oxide that acts as an osmotic laxative by binding water thus lessening desiccation to maintain the flexibility of muscles and organs. Fortunately, there are no known adverse health effects of PEG, and even if it is ingested, it is inert and not metabolized within the gastrointestinal tract (Brenner, 2014, Chassagne et al., 2017, Moore et al., 2008). Polyethylene glycol 400 in combination with ethanol serves to preserve moisture in embalmed cadavers (Bradbury and Hoshino, 1978) and to act as an inhibitor of mould growth (Macdonald and Mac-Gregor, 1997). The fixative and preservation properties of PEG and ethanol together kept cadavers free of mould and reduced bacterial loads (Steinmann, 1982). Similarly, the combination was used for the same purpose in the preservation flu- ids developed by Thiel, where embalming fluids were based on low concentrations of formaldehyde (1.4\%) (Thiel, 1992a, b, 2002). The results of our study confirm the disinfectant properties of the embalming solution used in this study for embalming cadavers (Table 1 ).

In the present study, Clostridium sporogenes and C. tyrobutyricum were isolated from skeletal muscles of two sheep cadavers. Both organisms are anaerobic Gram-positive bacteria that are usually found in soil and only colonize animals as part of the normal saprophytic flora where they have a symbiotic rather than a pathogenic interaction with the host (Logan and De Vos, 2009). Whilst C. tyrobutyricum is found commonly in soil, it has been isolated from silage, milk, and spoilt cheese (Bergere and Lenoir, 2000, Bergère and Sivelä, 1990). The C. sporogenes and C. tyrobutyricum cul-tured from animal cadavers are most likely environmental saprophytic contaminants that proliferate following death (Logan and De Vos, 2009).

In this study, the Paenisporosarcina $\mathrm{sp}$. isolated from the thoracic longissimus muscle of a horse is a gram positive, aerobic, spore-forming, rodshaped bacterium mostly isolated from soil (Krishnamurthi et al., 2009). This Paenisporosarcina sp. is most likely an environmental saprophyte. 
Colonies of the aerobic Bacillus licheniformis were cultivated from the duodenum and colon in all horses. In addition, Paenibacillus $s p$. was cultured from the colon of one horse, and Bacillus sp. cultured from the duodenum of the goat. Bacillus licheniformis is one of the most ubiquitous species of its genus and has been isolated from raw milk and along the dairy processing continuum (Kalogridou-Vassiliadou, 1992, Scheldeman et al., 2006). Bacillus licheniformis has become increasingly recognized as a human pathogen causing sepsis, mainly in immunocompromised patients (Blue et al., 1995, Haydushka et al., 2012, Ozkocaman et al., 2006). Whilst the organisms isolated in this study are probably innocuous saprophytic bacteria proliferations in the animal cadavers, their potential pathogenic nature warrants specific safety precautions to avoid accidental transmission from cadavers to humans.

Historically the use of formaldehyde at concentrations of up to $10 \%$ was used commonly to embalm cadavers worldwide (IARC, 2006, Kunz and Wilcke, 1991, Lischka et al., 1979). This resulted in humans being exposed to formaldehyde fumes possibly adversely affecting their health (IARC, 2006, Wantke et al., 2000). The main concern with formaldehyde is long term exposure to its fumes causing irritation to the mucous membranes in the nose and throat, difficulty in breathing, asthmatic symptoms, leukaemia and rarely nasal sinus cancer and nasopharyngeal cancer (IARC, 2006). In today's world, embalming of specimens for the teaching of veterinary anatomy has moved away from using high concentrations of formaldehyde to alternate formulations using low concentrations of formaldehyde, around $2 \%$, or even no formaldehyde (Elnady, 2016, Janczyk et al., 2011b, Lombardero et al., 2017, Steinke et al., 2008, Turan et al., 2017). Other than reducing the concentration of formaldehyde used in embalming fluids, exposure levels to formaldehyde fumes can be reduced by improved air ventilation and maintaining the room temperature below $19 \circ \mathrm{C}$ (Janczyk et al., 2011b). Designing dissection facilities to have laminar airflow from the ceiling down past the breathing zone to extraction at floor level has been adopted extensively (Coleman, 1995, Coleman and Kogan, 1998, Martin et al., 1995). Simply ensuring that handling and dissection of cadavers at $19{ }^{\circ} \mathrm{C}$ or lower, considerably lessens the concentration of formaldehyde fumes as the boiling point of formaldehyde is 19 ○C (Janczyk et al., 2011b).

In this study the concentration of formaldehyde fumes measured in the breathing zone was found to be $0.05-0,15 \mathrm{mg} / \mathrm{m}^{3}$ which is lower than 
$0.3 \mathrm{ppm}$, the Maximum Allowable Concentration stipulated by the German Research Foundation (NIH, 2009). These results confirm the results of Whitehead and Savoia (2008), who found that levels of formaldehyde vapours in the dissecting laboratory can be reduced up to $50 \%$ by using embalming fluid with a $2 \%$ formaldehyde concentration. Fixation using low formaldehyde concentrations in combination with ethanol and polyethylene glycol inhibits microbial growth on animal cadavers, appears to pose little health risk and, is environmentally friendly, cost effective, and results in cadavers having near natural colour and texture of their tissues and organs.

\section{Acknowledgement}

We wish to thank Professor Johanna Plendl from the Institute of Veterinary Anatomy, Department of Veterinary Medicine for all her help and guidance. We would like to thank Ms. Janet Weigner and Mr. Florian Grabitzky for their help in the collection of the samples. We would like also to thank Dr. Antina LübkeBecker for her help in microbial culture of the samples.

\section{References}

Abdul-Wahab, S. A., En, S. C. F., Elkamel, A., Ahmadi, L. \& Yetilme- zsoy, K. (2015): A review of standards and guidelines set by international bodies for the parameters of indoor air quality. Atmospheric Pollution Research 6, 751-767.

Agency, U. S. E. P. (1989): Report to Congress on Indoor Air Quality, Volume II: Assessment and Control of Indoor Air Pollution. 4-14.

Al-Hayani, A. A., Hamdy, R. M., ElAziz, G. S. A., Badawoud, M. H., Aldaqal, S. \& Bedir, Y. (2011): Shellac: A non-toxic preservative for human embalming techniques. Journal of Animal and Veterinary Advances 10, 1561-7.

Anichkov, N., Danilova, I., Vasiliev, O., Ryabinin, I. \& Kipenko, A. (2011): Use of a polyguanidine solution for fixing biological and anatomical specimens. Neuroscience and Behavioral Physio-logy 41, 1821.

Balta, J. Y., Cronin, M., Cryan, J. F. \& O'Mahony, S. M. (2015): Human preser-vation techniques in anaomy: A 21st century medical education perspective. Clinical Anatomy $28,725-34$.

Barsan, M. E. (2007): NIOSHA Pocket Guide to Chemical Hazards. National Institute for Occupational Safety and Health Ohio. 
Bergere, J. L. \& Lenoir, J. (2000): Cheese manufacturing accidents and cheese defects. Cheesemaking: From science to quality assurance, (Ed. 2). Intercept Limited: United Kingdom.

Bergère, J. L. \& Sivelä, S. (1990): De-tection and enumeration of clostridial spores related to cheese quality-classical and new methods. Bulletin of the Inter-national Dairy Federation 251, 18-23.

Blue, S. R., Singh, V. R. \& Saubolle, M. A. (1995): Bacillus licheniformis bacteremia: five cases associated with indwell-ing central venous catheters. Clinical Infectious Diseases 20, 629-33.

Bradbury, S. A. \& Hoshino, K. (1978): An improved embalming procedure for long-lasting preservation of the cadaver for anatomical study. Acta Anatomica 101, 97-103.

Brenner, E. (2014). Human body preservaion - old and new techniques. Journal of Anatomy 224, 31644.

Chassagne, P., Ducrotte, P., Garnier, P. \& Mathiex-Fortunet, H. (2017): Tole-rance and long-term efficacy of poly-ethylene glycol 4000 (Forlax ${ }^{\circledR}$ ) com-pared to lactulose in elderly patients with chronic consti- pation. The journal of nutrition, health \& aging 21, 429-439.

Chia, S. E., Ong, C. N., Foo, S. C. \& Lee, H. P. (1992): Medical students' exposure to formaldehyde in a gross anatomy dissection laboratory. Journal of American College Health 41, 115-9.

Coleman, R. (1995): Reducing the levels of formaldehyde exposure in gross anatomy laboratories. The Anatomical Record 243, 531-3.

Coleman, R. \& Kogan, I. (1998): An improved low-formaldehyde embalming fluid to preserve cadavers for anatomy teaching. Journal of Anatomy 192, 443-6.

Coskey, A. \& Gest, T. R. (2015): Effec-tiveness of various methods of formal-dehyde neutralization using mono-ethanolamine. Clinical Anatomy $28,449-54$.

Dixit, D., Athavia, P. D. \& Pathak, H. M. (2005): Toxic effects of embalming fluid on medical students and pro-fessionals. Journal of Indian Aca-demy of Forensic Medicine 27, 209-211.

Elnady, F. A. (2016): The Elnady Tech-nique: An innovative, new method for tissue preservation. ALTEX 33, 237-42. 
Haizuka, Y., Nagase, M., Takashino, S., Kobayashi, Y., Fujikura, Y. \& Mat-sumura, G. (2018): A new substitute for formalin: Application to embalming cadavers. Clinical Anatomy 31, 90-98.

Hammer, N., Loffler, S., Feja, C., Sandrock, M., Schmidt, W., Bechmann, I. \& Steinke, H. (2012): Ethanolglycerin fixation with thymol conservation: a potential alternative to formaldehyde and phenol embalming. Anatomical Sciences Education 5, 225-33.

Haydushka, I. A., Markova, N., Kirina, V. \& Atanassova, M. (2012): Recurrent sepsis due to bacillus licheniformis. Journal of Global Infectious Diseases 4, 82-3.

IARC (2006): Formaldehyde, 2Buto-xyethanol and 1-tert-Butoxypropan-2-ol. IARC Monographs on the Evaluation of Carcinogenic Risks to Humans. World Health Organization, International Agency for Research on Cancer, Albert Thomas: France.

Janczyk, P., Weigner, J., LuebkeBecker, A., Kaessmeyer, S. \& Plendl, J. (2011a): Nitrite pickling salt as an alternative to formaldehyde for embalming in veterinary anatomy, A study based on histo- and microbiological analyses. AnnaIs of Anatomy 193, 71-5.

Janczyk, P., Weigner, J., LuebkeBecker, A., Richardson, K. C. J. \& Plendl, J. (2011b): A pilot study on ethanol-polyethyleneglycol-formalin fixation of farm animal cadavers. Berliner und Munchener Tierarz tliche Wochen-schrift 124, 10-12.

Kalogridou-Vassiliadou, D. (1992): Biochemical activities of Bacillus species isolated from flat sour evaporated milk. Journal of Dairy Science 75, 2681-6.

Kerns, W. D., Pavkov, K. L., Donofraio, D. J., Gralla, E. J. \& Swenberg, J. A. (1983): Carcinogenicity of formaldehyde in rats and mice after long-term inhalation exposure. Cancer Research 43, 4382-92.

Kim, W. J., Terada, N., Nomura, T., Takahashi, R., Lee, S. D., Park, J. H. \& Konno, A. (2002): Effect of formaldehyde on the expression of adhesion molecules in nasal microvascular endothelial cells: the role of formaldehyde in the pathogenesis of sick building syndrome. Clinical and Experi-mental Allergy 32, 287-95.

Kriebel, D., Sama, S. R. \& Cocanour, B. (1993): Reversible pulmonary responses to formaldehyde. A study of clinical anatomy students. 
The American Review of Respiratory Disease 148, 1509-15.

Krishnamurthi, S., Bhattacharya, A., Mayilraj, S., Saha, P., Schumann, P. \& Chakrabarti, T. (2009): Description of Paenisporo-sarcina quisquiliarum gen. nov., sp. nov., and reclassification of Sporosarcina macmurdoensis Reddy et al. 2003 as Paenisporosarcina macmur-doensis comb. nov. International Journal of Systematic and Evolutionary Microbiology 59, 1364-70.

Kunz, G. \& Wilcke, G. (1991): Untersuchungen zur Konservierung biologi-schen Materials unter dem Aspekt der Formaldehydreduzierung. Der Präpara-tor 38, 63-74.

Lischka, M. F., Wewalka, G., Stanek, G. \& Krammer, E. B. (1979): Comparison of disinfectant activity of 3 different embalming fluids on cadavera for anatomical study. Anatomischer Anzei-ger 146, 295-306.

Logan, N. A. \& De Vos, P. (2009): Genus I. Clostridium Prazmowski 1880, in: Vos, P.D., Garrity, G., Jones, D., Krieg, N.R., Ludwig, W., Rainey, F.A., Schleifer, K.-H., Whitman, W.B. (Eds.), Bergey's Manual of Systematic Bac-teriology, Volume 3: The Firmicutes. Springer Dordrecht Heidelberg London New York.
Lombardero, M., Yllera, M. M., Costa, E. S. A., Oliveira, M. J. \& Ferreira, P. G. (2017): Saturated salt solution: a further step to a formaldehyde-free embalming method for veterinary gross anatomy. Journal of Anatomy 231, 309-317.

Macdonald, G. J. \& MacGregor, D. B. (1997): Procedures for embalming cadavers for the dissecting laboratory. Proceedings of the Society for Experi-mental Biology and Medicine 215, 363-5.

Martin, W. D., Nemitz, J. W., Hendley, A., Fisk, R. M. \& Wells, J. P. (1995): Three years of experience with a dissection table ventilation system. Clinical Anatomy 8, 297302.

Moore, M. M., Kanekar, S. G. \& Dhamija, R. (2008): Ethylene Glycol Toxicity: Chemistry, Pathogene-sis, and Imaging. Radiology Case Reports 3, 122.

Murray, P. R., Baron, E. J., Jorgensen, J. H., Landry, M. L. \& Pfaller, M. A. (2007): Manual of Clinical Microbiology. 9th edition. ASM Press, Washington, DC.

NIH (2009): Hazardous Substances Data Bank. National Institute of Health. U.S. National Library of Medicine. 
Ozkocaman, V., Ozcelik, T., Ali, R., Ozkalemkas, F., Ozkan, A., Ozakin, C., Akalin, H., Ursavas, A., Coskun, F., Ener, B. \& Tunali, A. (2006): Bacillus spp. among hospitalized patients with haematological malignancies: clinical features, epidemics and outcomes. Journal of Hospital Infection 64, 169-76.

Pretorius, W. (1995): Formula for embalming of cadavers for student dissection and the modification thereof for plastination. The Journal of Plas-tination, International Society For Plasti-nation 9, 35-36.

Scheldeman, P., Herman, L., Foster, S. \& Heyndrickx, M. (2006): Bacillus sporothermodurans and other highly heat-resistant spore formers in milk. Journal of Applied Microbiology 101, 542-55.

Silva, R. M., Matera, J. M. \& Ribeiro, A. A. (2007): New alternative methods to teach surgical techniques for veterinary medicine students despite the absence of living animals. Is that an academic paradox? Anatomia, Histo-logia, Embryo-logia 36, 220-4.

Steinke, H., Rabi, S., Saito, T., Saw-utti, A., Miyaki, T., Itoh, M. \& Spanel-Borowski, K. (2008): Lightweight plas-tination. Annals of Anatomy 190, 428-31.
Steinmann, W. F. (1982): Makroskopische Präparationsmethoden in der Medizin. Thieme Verlag: Germany.

Tanaka, K., Nishiyama, K., Yaginuma, H., Sasaki, A., Maeda, T., Kaneko, S. Y., Onami, T. \& Tanaka, M. (2003): Formaldehyde exposure levels and exposure control measures during an anatomy dissecting course. Kaibogaku Zasshi. Journal of Anatomy 78, 43-51.

Thiel, W. (1992a): Die Konservierung ganzer leichen in natürlichen farben. Annals of Anatomy-Anatomischer Anzei-ger 174, 185-195.

Thiel, W. (1992b): Eine Arterienmasse zur Nachinjektion bei der Konser-vierung ganzer Leichen. Annals of Anatomy-Anatomischer Anzeiger 174, 197-200.

Thiel, W. (2002): Ergänzung für die Konservierung ganzer Leichen nach W. Thiel. Annals of Anatomy-Anatomischer Anzeiger 184, 267-269.

Turan, E., Gules, O., Kilimci, F. S., Kara, M. E., Dilek, O. G., Sabanci, S. S. \& Tatar, M. (2017): The mixture of liquid foam soap, ethanol and citric acid as a new fixative-preservative solution in veterinary anatomy. Annals of Anatomy 209, 11-17. 
Wantke, F., Focke, M., Hemmer, W., Bracun, R., Wolf-Abdolvahab, S., Götz, M., Jarisch, R., Tschabitscher, M., Gann, M. \& Tappler, P. (2000): Exposure to formaldehyde and phenol during an anatomy dissecting course: sensitizing potency of formaldehyde in medical students. Allergy 55, 84-87.

Whitehead, M. C. \& Savoia, M. C. (2008): Evaluation of methods to reduce formaldehyde levels of cadavers in the dissection laboratory. Clinical Anatomy 21, 75-81.
Corresponding author:

Ahmad Al Aiyan

Department of Veterinary Medicine United Arab Emirates University

Al Ain, 15551

United Arab Emirates

E-mail: a.alaiyan@uaeu.ac.ae

Send reprint request to Dr. A. Al Aiyan e-mail: a.alaiyan@uaeu.ac.ae 
Status of the cadavers fixed with low Formaldehyde concentration

Al Aiyan et al.,

Table (1): Results of microbiological examination of tissue samples collected from horses at 10 and 40 days post fixation and from small ruminants at 75 and 105 days post fixation.

\begin{tabular}{|c|c|c|c|c|c|c|c|c|}
\hline \multicolumn{9}{|c|}{ Microbial analysis } \\
\hline & $\begin{array}{l}\text { Microbiological } \\
\text { parameter }\end{array}$ & $\begin{array}{l}\text { Time after } \\
\text { fixation }\end{array}$ & $\begin{array}{l}\text { Muscles } \\
\text { superficial }\end{array}$ & $\begin{array}{l}\text { Muscles } \\
\text { deep }\end{array}$ & $\begin{array}{l}\text { Lung } \\
\text { superficial }\end{array}$ & $\begin{array}{l}\text { Lung } \\
\text { deep }\end{array}$ & Duodenum & Colon \\
\hline \multirow{6}{*}{$\begin{array}{l}\text { Horse } \\
\text { I }\end{array}$} & aerobic bacteria & \multirow{3}{*}{10 days } & - & - & & & & \\
\hline & anaerobic bacteria & & - & - & & & & \\
\hline & fungi & & - & - & & & & \\
\hline & \multirow{3}{*}{$\begin{array}{l}\text { aerobic bacteria } \\
\text { anaerobic bacteria } \\
\text { fungi }\end{array}$} & \multirow{3}{*}{40 days } & - & - & - & - & $+\mathrm{BL}$ & $+\mathrm{BL}$ \\
\hline & & & - & - & - & - & - & - \\
\hline & & & - & - & - & - & - & - \\
\hline \multirow{6}{*}{$\begin{array}{l}\text { Horse } \\
\text { II }\end{array}$} & \multirow{3}{*}{$\begin{array}{l}\text { aerobic bacteria } \\
\text { anaerobic bacteria } \\
\text { fungi }\end{array}$} & \multirow{3}{*}{10 days } & - & - & & & & \\
\hline & & & - & - & & & & \\
\hline & & & - & - & & & & \\
\hline & \multirow{3}{*}{$\begin{array}{l}\text { aerobic bacteria } \\
\text { anaerobic bacteria } \\
\text { fungi }\end{array}$} & \multirow{3}{*}{40 days } & - & - & - & - & $+\mathrm{BL}$ & $+\mathrm{BL}$ \\
\hline & & & - & - & - & - & - & - \\
\hline & & & - & - & - & - & - & - \\
\hline \multirow{6}{*}{$\begin{array}{l}\text { Horse } \\
\text { III }\end{array}$} & \multirow{3}{*}{$\begin{array}{l}\text { aerobic bacteria } \\
\text { anaerobic bacteria } \\
\text { fungi }\end{array}$} & \multirow{3}{*}{10 days } & - & - & & & & \\
\hline & & & - & - & & & & \\
\hline & & & - & - & & & & \\
\hline & aerobic bacteria & \multirow{3}{*}{40 days } & - & $+\mathrm{PS}$ & - & - & $+\mathrm{BL}$ & + BL, $\mathrm{PaS}$ \\
\hline & \multirow{2}{*}{$\begin{array}{l}\text { anaerobic bacteria } \\
\text { fungi }\end{array}$} & & - & - & - & - & - & - \\
\hline & & & - & - & - & - & - & - \\
\hline \multirow{6}{*}{$\begin{array}{l}\text { Sheep } \\
\text { I }\end{array}$} & aerobic bacteria & \multirow{3}{*}{75 days } & - & - & & & & \\
\hline & anaerobic bacteria & & - & - & & & & \\
\hline & fungi & & - & - & & & & \\
\hline & aerobic bacteria & \multirow{3}{*}{105 days } & - & - & - & - & - & - \\
\hline & anaerobic bacteria & & - & - & - & - & - & - \\
\hline & fungi & & - & - & - & - & - & - \\
\hline \multirow{6}{*}{$\begin{array}{l}\text { Sheep } \\
\text { II }\end{array}$} & aerobic bacteria & \multirow{3}{*}{75 days } & - & - & & & & \\
\hline & anaerobic bacteria & & - & - & & & & \\
\hline & fungi & & - & - & & & & \\
\hline & aerobic bacteria & \multirow{3}{*}{105 days } & - & - & - & - & - & - \\
\hline & anaerobic bacteria & & $+\mathrm{CS}$ & - & - & - & - & - \\
\hline & fungi & & - & - & - & - & - & - \\
\hline \multirow{6}{*}{$\begin{array}{l}\text { Sheep } \\
\text { III }\end{array}$} & aerobic bacteria & \multirow{3}{*}{75 days } & - & - & & & & \\
\hline & anaerobic bacteria & & - & - & & & & \\
\hline & fungi & & - & - & & & & \\
\hline & aerobic bacteria & & - & - & - & - & - & - \\
\hline & anaerobic bacteria & 105 days & $+\mathrm{CT}$ & - & - & - & - & - \\
\hline & fungi & & - & - & - & - & - & - \\
\hline & aerobic bacteria & & - & - & & & & \\
\hline & anaerobic bacteria & 75 days & - & - & & & & \\
\hline & fungi & & - & - & & & & \\
\hline Goat & aerobic bacteria & & - & - & - & - & $+\mathrm{BS}$ & - \\
\hline & anaerobic bacteria & 105 days & - & - & - & - & - & - \\
\hline & fungi & & - & - & - & - & - & - \\
\hline
\end{tabular}

- = Microbiological tests negative

$+=$ Microbiological tests positive

$\mathrm{BL}=$ Bacillus licheniformis

$\mathrm{PS}=$ Paenisporosarcina $s p$.

PaS $=$ Paenibacillus $s p$.

$\mathrm{CS}=$ Clostridium sporogenes

$\mathrm{CT}=$ Clostridium tyrobutyricum

$\mathrm{BS}=$ Bacillus $s p$. 


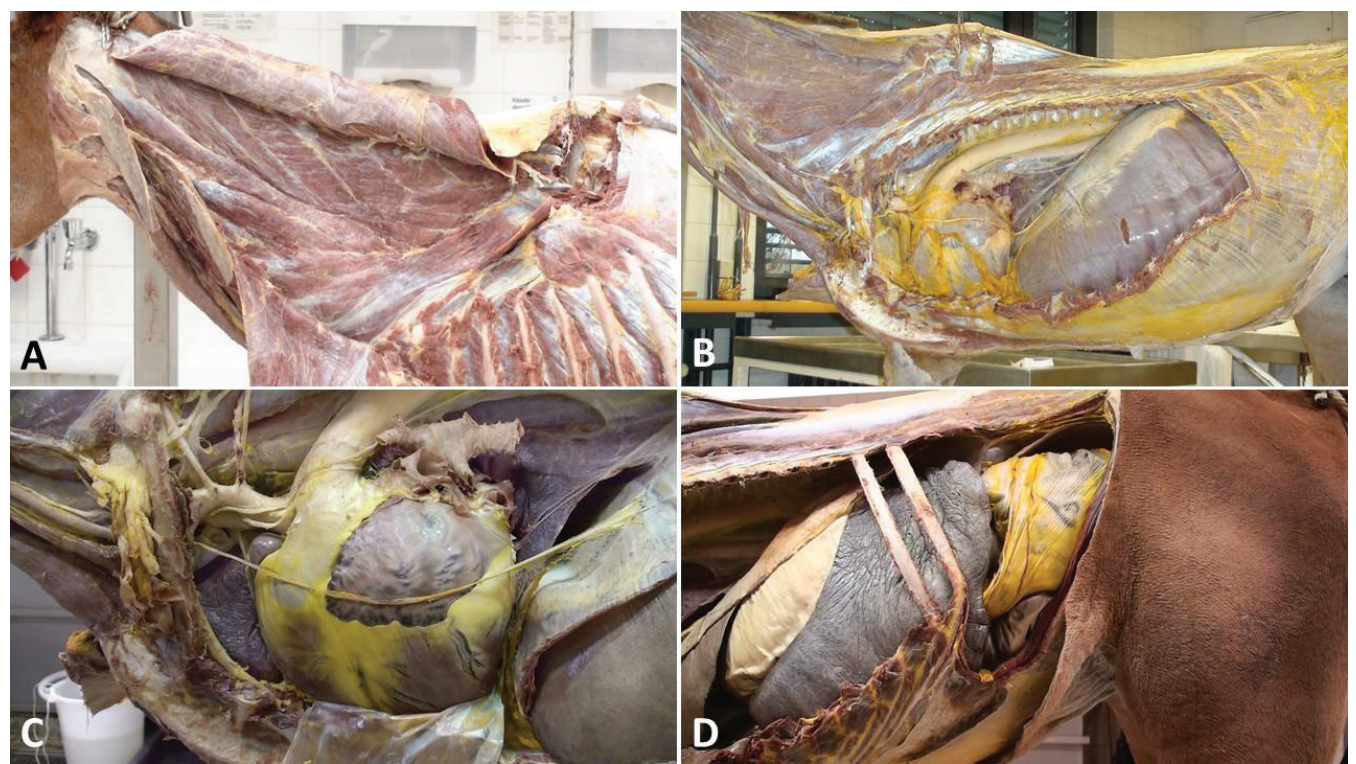

Fig (1): Fixed horse cadavers. Deep muscles of the neck, 30 days after embalming (A), deep muscles of the neck and thorax, intrathoracic organs and diaphragm, 40 days after embalming (B), intrathoracic organs, 50 days after embalming $(C)$, intra-abdominal organs, 60 days after embalming (D).

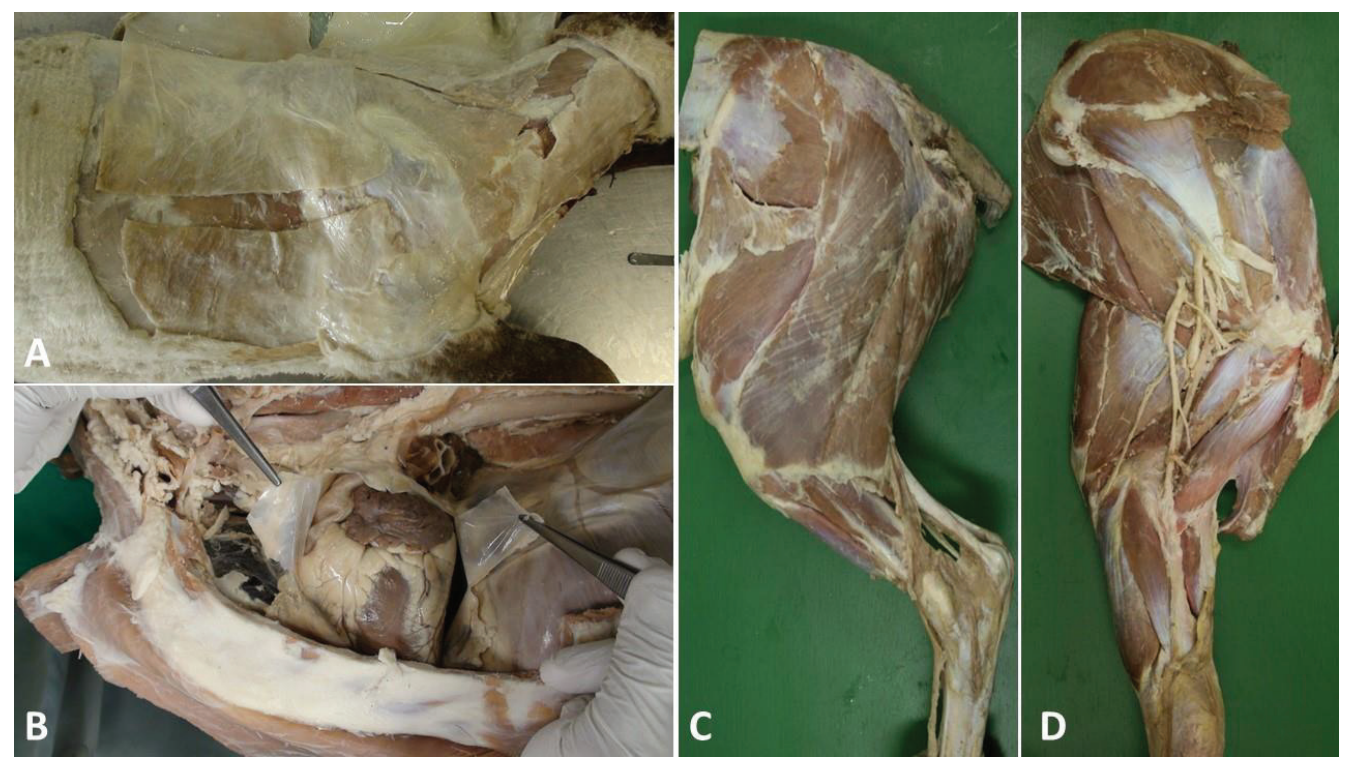

Fig (2): Fixed sheep cadavers. Skin and cutaneous and superficial muscles, 70 days after embalming (A), intrathoracic organs and diaphragm, 100 days after embalming (B), lateral muscles of hind limb, 150 days after embalming (C), medial muscles of forelimb,150 days after embalming (D). 